\title{
Effects of Different Land Uses (Abandoned Farmland, Intensive Agriculture and Forest) on Soil Hydrological Properties in Southern Spain
}

\author{
Manuel Esteban Lucas-Borja ${ }^{1}{ }^{(\mathbb{C},}$, Demetrio Antonio Zema ${ }^{2, *}{ }^{\circledR}$, Pedro Antonio Plaza-Álvarez ${ }^{1}$, \\ Vesna Zupanc ${ }^{3}{ }^{\mathbb{D}}$, Jantiene Baartman ${ }^{4}$, Javier Sagra ${ }^{1}{ }^{\mathbb{D}}$, Javier González-Romero ${ }^{1}$, \\ Daniel Moya ${ }^{1}$ (D) and Jorge de las Heras ${ }^{1}$ \\ 1 Escuela Técnica Superior Ingenieros Agrónomos y Montes, Universidad de Castilla-La Mancha, Campus \\ Universitario, E-02071 Albacete, Spain; manuelestaban.lucas@uclm.es (M.E.L.-B.); \\ pedro.plaza@uclm.es (P.A.P.-Á.); javier.sagra@uclm.es (J.S.); Javier.Gonzalez@uclm.es (J.G.-R.); \\ Daniel.Moya@uclm.es (D.M.); Jorge.Heras@uclm.es (J.d.1.H.) \\ 2 Department AGRARIA, Mediterranean University of Reggio Calabria, Loc. Feo di Vito, \\ I-89122 Reggio Calabria, Italy \\ 3 Department of Agronomy, Biotechnical Faculty, University of Ljubljana, Jamnikarjeva 101, 1000 Ljubljana, \\ Slovenia; vesna.zupanc@bf.uni-lj.si \\ 4 Soil Physics and Land Management Group, Wageningen University, 6708 WG Wageningen, \\ The Netherlands; jantiene.baartman@wur.nl \\ * Correspondence: dzema@unirc.it; Tel.: +39-0965-1694295
}

Received: 2 February 2019; Accepted: 6 March 2019; Published: 11 March 2019

check for updates

\begin{abstract}
A detailed knowledge of soil water repellency (SWR) and water infiltration capacity of soils under different land uses is of fundamental importance in Mediterranean areas, since these areas are prone to soil degradation risks (e.g., erosion, runoff of polluting compounds) as a response to different hydrological processes. The present study evaluates the effects of land uses on SWR and soil hydraulic conductivity (SHC) by direct measurements at the plot scale in three areas representing (1) intensive agricultural use, (2) abandoned farmland, and (3) a forest ecosystem in Southern Spain under Mediterranean climatic conditions. The physico-chemical properties and water content of the experimental soils were also measured. Significant SWR and SHC differences were found among the analyzed land uses. Forest soils showed high SWR and low SHC, while the reverse effects (that is, low SWR and high SHC) were detected in soils subjected to intensive agriculture. Organic matter and bulk density were important soil properties influencing SWR and SHC. The study, demonstrating how land uses can have important effects on the hydrological characteristics of soils, give land managers insights into the choice of the most suitable land use planning strategies in view of facing the high runoff and erosion rates typical of the Mediterranean areas.
\end{abstract}

Keywords: soil water repellency; soil hydrological conductivity; soil physico-chemical properties; vegetal cover; vegetation cover

\section{Introduction}

Mediterranean areas are very prone to soil degradation risks (e.g., surface runoff, erosion, transport of nutrients and other polluting compounds): the soils are generally shallow with low levels of organic matter, low aggregate stability, and nutrient content [1], and the climate is characterized by frequent and intense rainstorms producing a high magnitude of flash floods with high erosive power [2]. This combination of soil type and climate leads to a peculiar hydrological response with high runoff rates that have high erosive power. This response is also affected by both land use and 
soil cover and their temporal and spatial variability, which are considered the most important factors affecting the intensity and frequency of surface runoff and soil erosion [3,4]. Inappropriate land use or a poor soil cover may accelerate water runoff and soil erosion dynamics [4,5], leading to unsustainable land degradation processes. The main causes of such negative environmental impacts are agricultural practices, deforestation, overgrazing, land abandonment, wildfires, and civil works [6,7]. For instance, agriculture is thought to generate high erosion rates $[4,8,9]$, and the use of land for intensive agriculture, in general, may cause soil damage $[10,11]$. As well known, agriculture, particularly when intensive and subject to frequent tillage operations, may strongly affect the physico-chemical properties of soil, making it more prone to erosion and quality decay.

Erosion problems have also been associated with land abandonment of both agricultural and marginal farmlands [1,12] with particular reference to the Mediterranean of Western Europe $[9,13,14]$. For instance, in SE Spain, where drastic human impacts were recorded in the second half of the past century [15], anthropogenic land use changes have triggered soil erosion and led to severe land degradation [1]. Here, since the mid-twentieth century, the use of land for intensive agriculture and the gradual process of vegetation recovery of abandoned farmlands and marginal areas have been the main causes of land degradation $[10,11]$. These land use changes, whose environmental impacts are worsened by the specific climate and the soil fragility, make this region very prone to runoff generation and soil erosion [3] with consequent pollution of water bodies, soil organic matter decline, devastating floods, reservoir siltation, and mass failures $[1,15]$.

In Mediterranean areas, the hydrological processes generating water runoff, soil erosion, and transport of polluting compounds are dominated by the infiltration-excess mechanism [16]. In soils of the semi-arid Mediterranean climate, exhibiting low hydraulic conductivity, surface runoff, and soil erosion, can be high. Moreover, such soils could be expected to also be affected by water repellency [17,18], further decreasing infiltration rates [19], which in turn leads to increased runoff and erosion [20,21], to accelerated leaching of agrochemicals [22], and to a reduction in the vegetal cover of soils, leaving the latter bare and thus prone to erosion [23,24]. Thus, depending on the water repellency level, Mediterranean soils may have an infiltration rate of up to several orders of magnitude lower than would be expected (e.g., $[20,21,25,26])$. It is thus evident how a detailed knowledge of the soil water repellency (hereinafter SWR) and water infiltration capacity (in terms of soil hydraulic conductivity, hereinafter SHC) under different land uses is of fundamental importance in Mediterranean areas to control hydrological risks and other environmental impacts linked to these risks.

SWR has been studied worldwide [20,21], in both forest [27] and agricultural soils [24,28]. The agricultural soils are usually considered wettable [29] and thus a little subject to SWR, while other studies have demonstrated that some management practices may induce SWR in cultivated soils [30-32]. The attention paid to surface runoff and soil erosion rates in marginal and abandoned lands (e.g., [33]) has highlighted sometimes contrasting results in the Mediterranean [34] and, consequently, the difficulty to fully understand the effects of land abandonment on hydrological response and soil erosion [9], as modified by both SWR and SHC. Therefore, it is important to know about repellency and infiltration under typical land uses in the drier parts of the Mediterranean basin [18]. A better comprehension of these fundamental soil parameters is important for both agricultural production and protection of abandoned farmland from hydro-geological risks [24].

This study evaluates the effects of land use on SWR and SHC by direct measurements at the plot scale in three areas representing (1) intensive agricultural use, (2) abandoned farmland, and (3) a forest ecosystem in Southern Spain. In addition, the physico-chemical properties and water content, which, as it is well known, can influence SWR and SHC, were also measured on these representative Mediterranean soils. The objective of the study is to evaluate which of the analyzed land uses (agriculture, abandoned farmland and forest) shows the highest SWR and lowest SHC in the experimental conditions, also linking these properties to important soil characteristics. By demonstrating how land uses can have important effects on the hydrological characteristics of soils, 
we want to give land managers insights on the choice of the most suitable land use planning in view of facing the high runoff and erosion rates typical of the Mediterranean areas.

\section{Materials and Methods}

\subsection{Study Area}

The study area is located in the municipality of Villamalea $\left(39.36422^{\circ} \mathrm{N},-1.59689^{\circ} \mathrm{E}\right.$, Albacete, SE Spain) (Figure 1). The climate is typically Mediterranean, "Csa", according to the Köppen-Geiger classification [35]. The average annual rainfall and temperature are $407 \mathrm{~mm}$ and $14{ }^{\circ} \mathrm{C}$, respectively (Figure 2). The rainfall is mainly distributed in spring and autumn, with a long drought in summer that usually lasts from June-September.

Elevation of the studied plots ranges between 760 and $770 \mathrm{~m}$ a.s.l., a flat terrain, typical for the Iberian Plateau (Meseta). The plateau is characterized by high elevated (>600 $\mathrm{m}$ a.s.1.) region with an undulating (hilly) landscape that is prone to high erosion rates due to the dry climate conditions that reduce the vegetation cover.

The study area is a traditional Mediterranean forest and agricultural land, where pine plantations, natural forest, almonds, olive, cereals, and vineyards are widespread (Figure 1). The natural tree vegetation of the study area mainly consists of Pinus pinea L. and Pinus halepensis M. The main shrubs and herbaceous species found at the study site are Rosmarinus officinalis L., Brachypodium retusum (Pers.) Beauv., Lavandula latifolia Medik., Thymus vulgaris L., Stipa tenacissima (L.), Quercus coccifera L. and Plantago albicans L. Agriculture consists mainly of vineyards, olive orchards and maize crops, with vine production providing the main agricultural income in the study region.
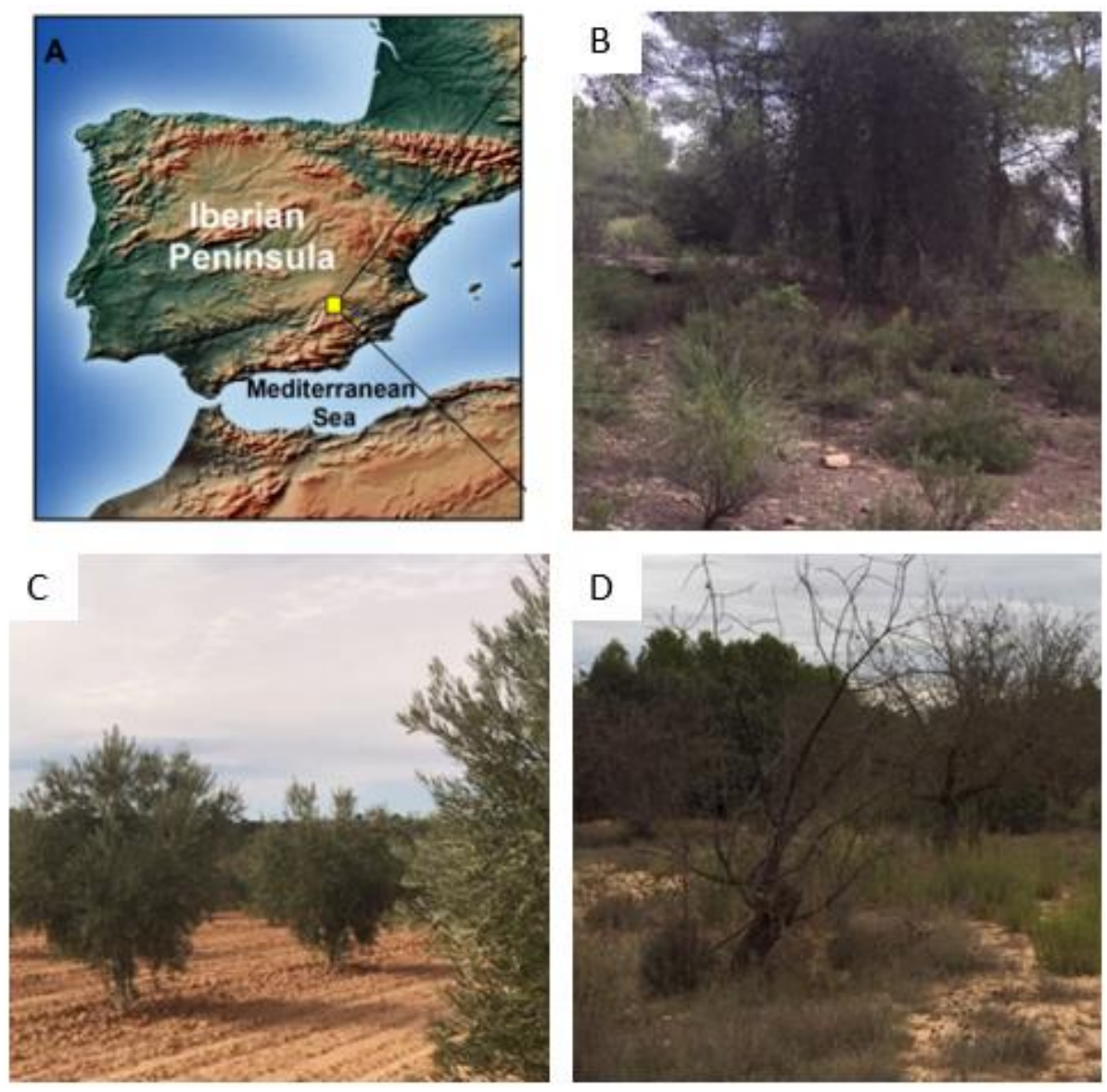

Figure 1. Location of the study area (A, Villamalea, Castilla La Mancha, SE Spain) with the typical land uses (B: Forest; C: Intensive agriculture; D: Abandoned farmland). 


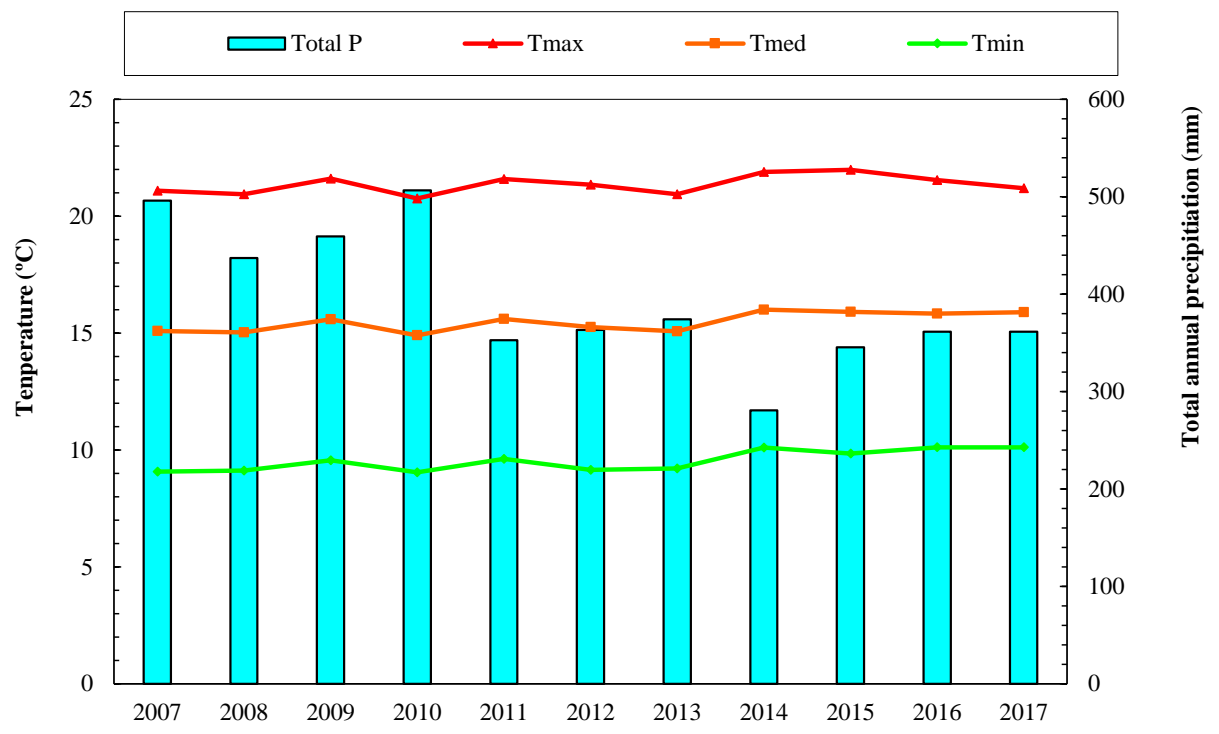

Figure 2. Annual precipitation (total $\mathrm{P}, \mathrm{mm}$ ) as well as mean maximum, average and minimum air temperatures ( $\mathrm{T}_{\max }, \mathrm{T}_{\text {med }}$ and $\left.\mathrm{T}_{\min }\right)$ in the study area (Villamalea, Castilla La Mancha, SE Spain).

According to FAO-UNESCO [36] and the IUSS Working Group WRB [37], the soils of the study area are classified as Calcic cambisols. Organic matter content is on average $1.1 \mathrm{~g} / \mathrm{m}^{3}$, varying from $1.05-1.12 \mathrm{~g} / \mathrm{m}^{3}$. The texture is sandy clay loam $(60 \%$ sand, $10 \%$ silt, and $27 \%$ clay) over a limestone parent material.

\subsection{Experimental Design}

\subsubsection{Plot Description}

In autumn 2018, nine $10 \times 10 \mathrm{~m}^{2}$ plots were set up in each of the three land uses (27 plots in total) of the same study area with the typical climate and soil characteristics described in Section 2.1. The analyzed land uses were (1) intensive agriculture; (2) abandoned farmland; (3) natural forest. The plots with similar slopes (1-5\%) were distributed selecting certain site characteristics, slopes, and aspects to ensure comparability among the 27 plots. Distances between plots were always over $500 \mathrm{~m}$.

The land use related to intensive agriculture (hereinafter "IA") consisted of an olive grove about 20 years old. Cropping operations follow the usual standards of the local farmers. The orchard is tilled three times per year, scheduled depending on the soil moisture and weed removal needs. Tillage is carried out just before or on the occasion of weed germination in order to keep the soil surface clean and tidy and is refined by eliminating herbs near the trunk of each tree (in June or July) by hoes. No fertilizers are used in the olive grove. Residues of pruning, operated in February or March, are concentrated and burned at the margins of the grove, but not chipped, as usually made for other crops (e.g., citrus and apricots).

The abandoned farmland (hereinafter "AF") was an olive orchard, abandoned about 15 years ago and now mainly covered by herbs and shrubs (mainly Rosmarinus officinalis L., Brachypodium retusum (Pers.) Beauv., Lavandula latifolia Medik., Thymus vulgaris L., Macrochloa tenacissima L., Quercus coccifera L., Plantago albicans L. Eryngium campestre L., and Pistacia lentiscus L.).

Forest plots (hereinafter "FO") are covered by Pinus halepenis $\mathrm{M}$., about 50 years old, with a density of 560 trees per ha. Shrubs found underneath the trees are Quercus coccifera L. and Macrochloa tenacissima $\mathrm{L}$.

\subsubsection{Soil Property Measurements}

Herbal cover, rock fragments, dead woody matter, and bare soil covers were measured at three 5 -m transects in each plot, measuring the percent cover of each property over a grid of $1 \mathrm{~m} \times 1 \mathrm{~m}$. 
Bulk density was calculated on triple samples per plot as the weight of soil in a given volume of the core extracted by a small cylinder at a depth of $20-30 \mathrm{~cm}$. Soil water content (SWC) was estimated using a HOBOnet Soil Moisture Sensor, which integrates the field-proven ECH2O ${ }^{\mathrm{TM}} \mathrm{EC} 5$ Sensor and provides readings directly in volumetric water content. SWC was measured hourly for $24 \mathrm{~h}$ on the occasion of the SWR and SHC surveys and the measures were then averaged.

The main topsoil properties $(0-5 \mathrm{~cm})$ were determined on six samples per plot. A total of 162 soil samples ( 6 samples $\times 9$ plots $\times 3$ land uses) were collected. Soil characterization was carried out by measuring the following parameters: (i) texture (sand, silt and clay percentage) following the methodology of Guitian and Carballas (1976) [38]; (ii) soil organic matter (OM), estimated from organic carbon following the methodology proposed by Nelson and Sommers (1996) [39]; (iii) electrical conductivity (EC) and $\mathrm{pH}$, measured in deionized water (1:2.5 and 1:5 $\mathrm{w}: \mathrm{W}$, correspondingly) at $20^{\circ} \mathrm{C}$ [40]; (iv) content of (total nitrogen, using the Kjeldahl method [41]) and available phosphorus [42]); (v) content of potassium; magnesium; sodium; and calcium, exchangeable cations measured using the barium-chloridetriethanolamine method [43]).

Based on the parameters above, the carbon-to-nitrogen ratio $(\mathrm{C} / \mathrm{N})$ and cation exchange capacity (CEC) were calculated.

The water infiltration capacity of soils was estimated measuring SHC by a MiniDisk infiltrometer (MDI). In more detail, first the measured cumulative infiltration values (I, $[\mathrm{m}]$ ) were fitted against the measurement intervals ( $\mathrm{t},[\mathrm{s}])$, both given by MDI, using Equation (1):

$$
\mathrm{I}=\mathrm{C}_{1} \mathrm{t}+\mathrm{C}_{2} \sqrt{\mathrm{t}}
$$

and the coefficients $C_{1}[\mathrm{~m} / \mathrm{s}]$ and $C_{2}\left[\mathrm{~m} / \mathrm{s}^{1 / 2}\right]$ were estimated by interpolation. Coefficient $\mathrm{C}_{1}$ is related to SHC, and $\mathrm{C}_{2}$ is the sorptivity [44]. Then, $\mathrm{SHC}(\mathrm{k},[\mathrm{mm} / \mathrm{h}])$ was calculated using the following equation:

$$
\mathrm{k}=\frac{\mathrm{C}_{1}}{\mathrm{~A}}
$$

where coefficient $\mathrm{A}$ is a value relating the Van Genuchten parameters ( $\mathrm{n}$ and $\alpha$ ) for a certain soil type to the suction rate $\left(h_{0}\right)$ and the infiltrometer disk radius $(2.25 \mathrm{~cm})$. Entering the values of $n, \alpha$, and $h_{0}$ (assumed in this study to be equal to $-2 \mathrm{~cm}$ ) of the experimental soils in the table reported in the MDI manual [44], a value of 2.8 was derived for A. Equations (1) and (2) were proposed by Reference [45].

SWR was measured as follows: 15 drops of distilled water were released, using a pipette, on the soil surface of a 1-m transect, to homogenize the changing soil conditions; the time necessary for drops to infiltrate completely into the soil was measured by a stopwatch. Before measurement, litter cover was removed, and the soil surface was cleaned using a brush. The high number of replicates (ten points per plot) assured the best reliability for this measurement. The method used is recognized as one of the most appropriate for evaluating the SWR degree in field measurements [46].

\subsection{Statistical Analysis}

A one-way ANOVA (using land use as the independent factor) was applied to evaluate the statistical significance of the variations in soil cover, physico-chemical properties, SWR and SHC. All the plots were considered spatially independent. An independent Fisher's minimum significant difference test (LSD) was used for the post hoc analysis comparisons. A $p<0.05$ level of significance was adopted. It was not necessary to perform data transformations for the analysis. ANOVA assumes normality and this assumption was checked using QQ-plots. All measured variables were used to perform the principal component analysis (PCA), the latter being based on a Spearman rank correlation matrix, to reduce the dimensionality of the data set. The statistical analysis was performed by version 3.24 of the R Project for Statistical Computing. 


\section{Results}

The soil physical characteristics as measured for the three land uses are shown in Table 1 . The texture of the experimental soils was statistically similar between AF and IA; the texture of the FO soil was significantly different from the other land uses. In general, the soil was finer in the AF and IA land uses (clay loam and loam, respectively) and coarser in FO. Soils subject to IA were more compacted (mean bulk density of $1.25 \mathrm{~g} \mathrm{~cm}^{-3}$ ), while the FO soils had a lower bulk density $\left(0.83 \mathrm{~g} \mathrm{~cm}^{-3}\right)($ Table 1$)$.

Table 1. Soil physical characteristics (mean \pm standard deviation) in the study area (Villamalea, Castilla La Mancha, SE Spain). Different lower-case letters indicate statistically significant differences following LSD test $(P$-value $<0.05)$.

\begin{tabular}{|c|c|c|c|c|c|c|c|c|}
\hline $\begin{array}{l}\text { Land } \\
\text { Use * }\end{array}$ & $\begin{array}{c}\text { Sand } \\
(\%)\end{array}$ & $\begin{array}{l}\text { Silt } \\
(\%)\end{array}$ & $\begin{array}{l}\text { Clay } \\
(\%)\end{array}$ & $\begin{array}{c}\text { Bulk Density } \\
\left(\mathrm{g} \mathrm{cm}^{-3}\right)\end{array}$ & $\begin{array}{c}\text { Rock } \\
(\%)\end{array}$ & $\begin{array}{c}\text { Herbal Cover } \\
(\%)\end{array}$ & $\begin{array}{c}\text { Bare Soil } \\
(\%)\end{array}$ & $\begin{array}{c}\text { Dead Woody } \\
\text { Matter }(\%)\end{array}$ \\
\hline$I A$ & $46.0 \pm 9.9^{b}$ & $35.3 \pm 8.7^{a}$ & $18.7 \pm 9.7 \mathrm{ab}$ & $1.25 \pm 0.2^{\mathrm{a}}$ & $14.2 \pm 2.9^{\mathrm{a}}$ & $1.0 \pm 0.7^{b}$ & $72.8 \pm 3.8^{\mathrm{a}}$ & $33.3 \pm 5.7^{b}$ \\
\hline$A F$ & $32.9 \pm 12.2^{b}$ & $39.8 \pm 7.9^{\mathrm{a}}$ & $27.7 \pm 6.8^{a}$ & $1.10 \pm 0.3^{b}$ & $3.1 \pm 2.2^{b}$ & $32.4 \pm 4.9^{\mathrm{a}}$ & $31.1 \pm 2.8^{b}$ & $12.8 \pm 5.7^{c}$ \\
\hline FO & $70.0 \pm 10.1^{a}$ & $19.5 \pm 9.5^{b}$ & $10.3 \pm 6.7^{b}$ & $0.83 \pm 0.2^{c}$ & $10.0 \pm 2.2^{\mathrm{ab}}$ & $29.5 \pm 5.5^{\mathrm{a}}$ & $1.3 \pm 0.5^{c}$ & $59.1 \pm 6.6^{\mathrm{a}}$ \\
\hline
\end{tabular}

* AF: Abandoned Farmland; IA: Intensive Agriculture; FO: Forest.

The IA showed the lowest vegetation cover (on average only $1 \%$ of the total sampled area). This latter parameter was similar between the other land uses (about 30\% and not significantly different between abandoned farmland and FO). On average, only 1\% of the soil in the FO plots was bare against more than $70 \%$ in IA (Table 1). The percentage of dead woody matter (plant material less than $2 \mathrm{~mm}$ in diameter) was statistically significantly different for all land uses, being highest in FO plots, followed by IA and AF soils.

The soil chemical characteristics as measured in the three land uses are shown in Table 2. The values of $\mathrm{pH}$ (on average $8.5-8.7)$ and $\mathrm{EC}\left(0.21-0.24 \mathrm{mS} \mathrm{cm}^{-1}\right)$ were not significantly different among the investigated land uses. The OM content, in tune with the soil total carbon, was similar between $\mathrm{AF}$ and FO (mean values between 1.3 and 1.5\%), and significantly lower in IA (on average 0.6\%). OM was not correlated to dead woody matter, presumably due to the different mineralization levels of the investigated soils, on which the previous and current tillage practices may have played a role. Also, the contents of $\mathrm{P}, \mathrm{K}$, and cations $\left(\mathrm{Na}^{+}, \mathrm{Ca}^{++}\right.$and $\left.\mathrm{Mg}^{++}\right)$were significantly different between land uses. FO soils had the lowest concentrations (except for $\mathrm{Ca}^{++}$) and the AF the highest (except for P). Conversely, there were no statistically significant differences in $\mathrm{N}$ content (on average $0.05-0.1 \%$ ). Due to this, the $\mathrm{C} / \mathrm{N}$ ratio was quite similar among all the studied land uses (mean values between 11.9 and 16.3), in spite of the differences recorded in C mean contents (from $0.6 \%$ of IA to $1.5 \%$ of AF). Finally, CEC was significantly higher in AF (on average $16.3 \mathrm{meq} / 100 \mathrm{~g}$ of soil), while FO soils showed the lowest value $(6.8 \mathrm{meq} / 100 \mathrm{~g}$, this latter not significantly different from IA, $9.9 \mathrm{meq} / 100 \mathrm{~g})$ (Table 2).

Table 2. Soil chemical characteristics (mean \pm standard deviation) in the study area (Villamalea, Castilla La Mancha, SE Spain). Different lower-case letters indicate statistically significant differences following the LSD test $(P$-value $<0.05)$.

\begin{tabular}{|c|c|c|c|c|c|c|c|}
\hline Land Use * & $\begin{array}{l}\mathrm{pH} \\
(-)\end{array}$ & $\begin{array}{l}\text { OM } \\
(\%)\end{array}$ & $\begin{array}{c}\mathrm{C} \\
(\%)\end{array}$ & $\begin{array}{c}\mathrm{N} \\
(\%)\end{array}$ & $\begin{array}{c}\mathbf{P} \\
(\mathrm{ppm})\end{array}$ & $\begin{array}{c}\mathrm{K} \\
(\mathrm{meq} / 100 \mathrm{~g})\end{array}$ & $\begin{array}{c}\mathrm{Na} \\
(\mathrm{meq} / 100 \mathrm{~g})\end{array}$ \\
\hline$I A$ & $8.7 \pm 0.7^{\mathrm{a}}$ & $0.98 \pm 1.0^{b}$ & $0.56 \pm 0.2^{b}$ & $0.05 \pm 0.01^{\mathrm{a}}$ & $21.7 \pm 6.3^{\mathrm{a}}$ & $0.5 \pm 0.1^{b}$ & $0.32 \pm 0.11^{\mathrm{a}}$ \\
\hline$A F$ & $8.5 \pm 0.7^{a}$ & $2.7 \pm 0.9^{\mathrm{a}}$ & $1.5 \pm 0.5^{\mathrm{a}}$ & $0.10 \pm 0.05^{\mathrm{a}}$ & $8.1 \pm 2.1^{b}$ & $0.8 \pm 0.2^{a}$ & $0.35 \pm 0.10^{\mathrm{a}}$ \\
\hline FO & $8.7 \pm 0.6^{\mathrm{a}}$ & $2.2 \pm 0.8^{\mathrm{a}}$ & $1.3 \pm 0.5^{\mathrm{a}}$ & $0.08 \pm 0.03^{\mathrm{a}}$ & $7.4 \pm 1.1^{\mathrm{b}}$ & $0.2 \pm 0.1^{\mathrm{c}}$ & $0.10 \pm 0.05^{b}$ \\
\hline Land Use * & $\begin{array}{c}\text { Ca } \\
\text { (meq/100 g) }\end{array}$ & $\begin{array}{c}\mathrm{Mg} \\
\text { (meq/100 g) }\end{array}$ & $\mathrm{C} / \mathrm{N}$ & $\mathrm{K} / \mathrm{Mg}$ & $\mathrm{Ca} / \mathrm{Mg}$ & $\begin{array}{c}\text { CEC } \\
\text { (meq/100 g) }\end{array}$ & $\begin{array}{c}\mathrm{EC} \\
(\mathrm{mS} / \mathrm{cm})\end{array}$ \\
\hline$I A$ & $32.1 \pm 5.9^{b}$ & $1.3 \pm 0.3^{\mathrm{a}}$ & $11.9 \pm 3.7^{\mathrm{a}}$ & $0.3 \pm 0.1^{\mathrm{a}}$ & $24.1 \pm 5.9^{b}$ & $9.9 \pm 3.8^{\mathrm{ab}}$ & $0.21 \pm 0.03^{a}$ \\
\hline$A F$ & $41.5 \pm 7.9^{\mathrm{a}}$ & $1.6 \pm 0.3^{\mathrm{a}}$ & $14.2 \pm 3.5^{\mathrm{a}}$ & $0.5 \pm 0.1^{\mathrm{a}}$ & $25.8 \pm 6.2^{b}$ & $16.3 \pm 5.3^{\mathrm{a}}$ & $0.21 \pm 0.02^{\mathrm{a}}$ \\
\hline FO & $32.2 \pm 9.4^{\mathrm{a}}$ & $0.7 \pm 0.2^{b}$ & $16.3 \pm 8.2^{\mathrm{a}}$ & $0.3 \pm 0.1^{\mathrm{a}}$ & $43.9 \pm 7.7^{\mathrm{a}}$ & $6.8 \pm 3.8^{b}$ & $0.24 \pm 0.04^{\mathrm{a}}$ \\
\hline
\end{tabular}

* AF: Abandoned Farmland; IA: Intensive Agriculture; FO: Forest; OM: Organic Matter; CEC: Cation Exchange

Capacity; EC: Electrical Conductivity; C: Total carbon; N: Total nitrogen. 
The analysis of the hydrological properties of the investigated soils showed much higher mean SWR values on soil surface compared to measurements made at $2 \mathrm{~cm}$ below ground (4-fold, AF, and 20-fold, FO). Only in soils under IA, the surface, and below ground SWR were similar. Moreover, FO soils had the highest SWR at both investigated depth (on average $74 \mathrm{~s}$, on the soil surface and $3.5 \mathrm{~s}$, $2 \mathrm{~cm}$ below the ground), while the lowest values were measured in IA (2.5 s) on soil surface, and AF $(2.0 \mathrm{~s})$ at $2 \mathrm{~cm}$ below the ground. Soil water content was $10.0 \%$ for AF and FO and $15.2 \%$ for IA) at the date of measurements (Figure $3 a$ ).

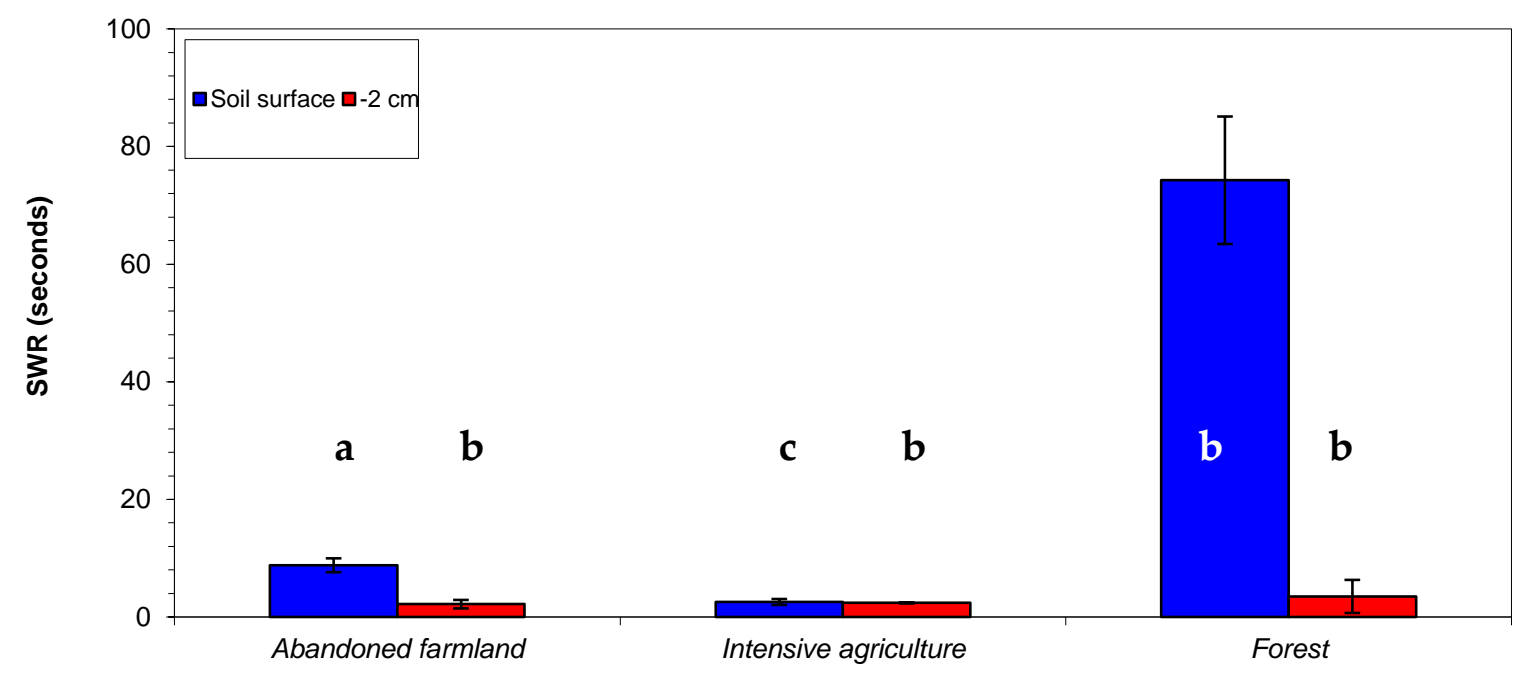

Land use

(a)

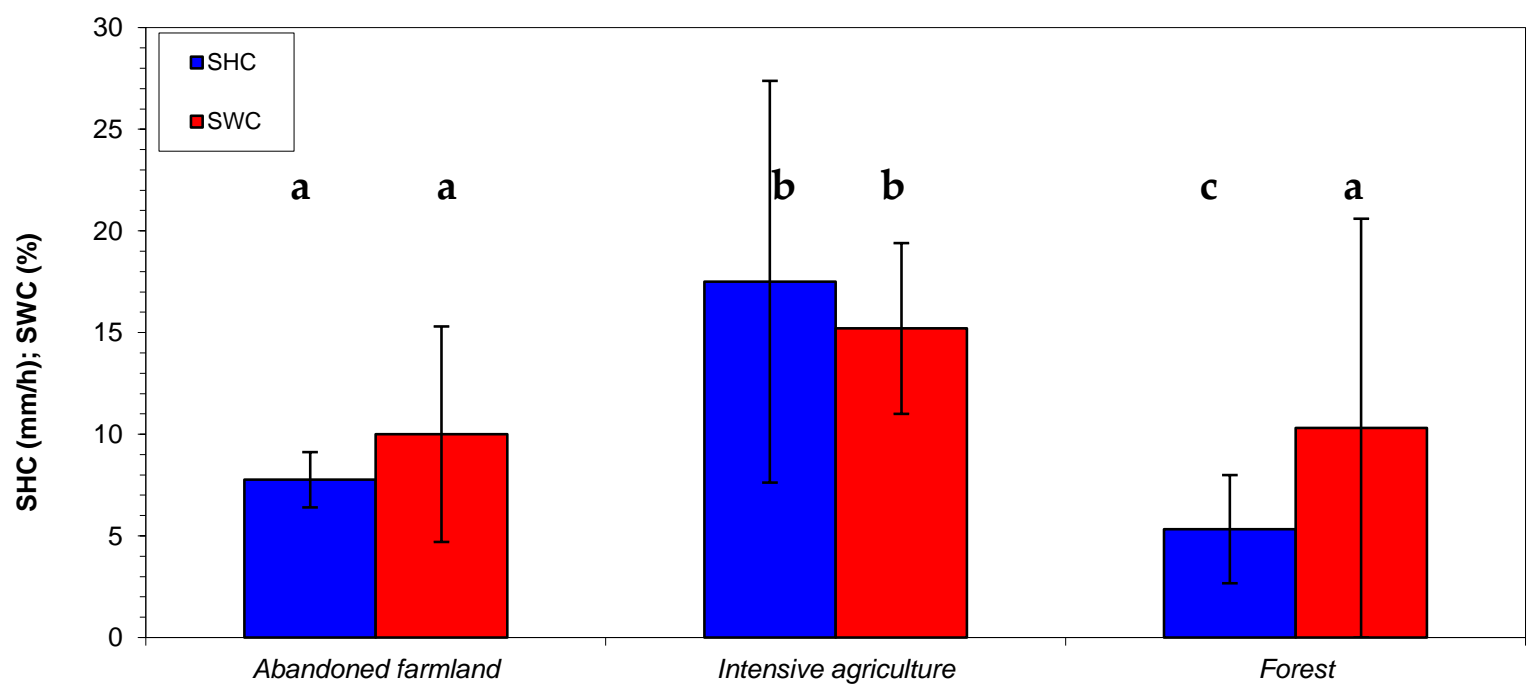

Land use

(b)

Figure 3. Soil water repellency (SWR, measured on the soil surface and at $2 \mathrm{~cm}$ below ground, (a), water content (SWC, b) and hydraulic conductivity (SHC, b) in the study area (Villamalea, Castilla La Mancha, SE Spain). Different lower-case letters indicate statistically significant differences comparing land uses for SWC and SHC following LSD test $(P$-value $<0.05)$. 
In soils under IA, the highest $\mathrm{SHC}$ was detected (on average $17 \mathrm{~mm} / \mathrm{h}$ ), while the FO soils showed the lowest values $(5 \mathrm{~mm} / \mathrm{h})$, similar (but significantly different) from SHC measured in the AF (mean value of $7 \mathrm{~mm} / \mathrm{h}$ ) (Figure $3 \mathrm{~b}$ and Table 3 ).

Table 3. Results of ANOVA applied to land uses (Abandoned Farmland; Intensive Agriculture; Forest) for soil water content (SWC), repellency (SWR) and hydraulic conductivity (SHC) in the study area (Villamalea, Castilla La Mancha, SE Spain).

\begin{tabular}{cccc}
\hline Soil Parameter * & Degree of Freedoms & F-Ratio & P-Value \\
\hline SWC & 2 & 28.9 & \\
SWR (soil surface) & 53.7 & $<0.05$ \\
SWR $(-2 \mathrm{~cm})$ & 34.7 & \\
SHC & 10.5 & \\
* SWC $=$ Soil Water Content; SWR = Soil Water Repellency; SHC = Soil Hydraulic Conductivity.
\end{tabular}

The PCA evidenced a clear clustering of the three investigated land uses with regard to the properties of soils, assumed as original variables (Figure 4). The $\mathrm{PC}_{1}$ and $\mathrm{PC}_{2}$ explained $51 \%$ and $37 \%$ (in total 88\%), respectively, of the total variance of the original variables (Table 4). EC, pH, CEC, and nutrient contents were the variables with the higher loading factors on $\mathrm{PC}_{1}$, whereas plot \% of vegetation cover, bare soil, dead woody matter, total carbon content, and bulk density showed the higher loadings on $\mathrm{PC}_{2}$.

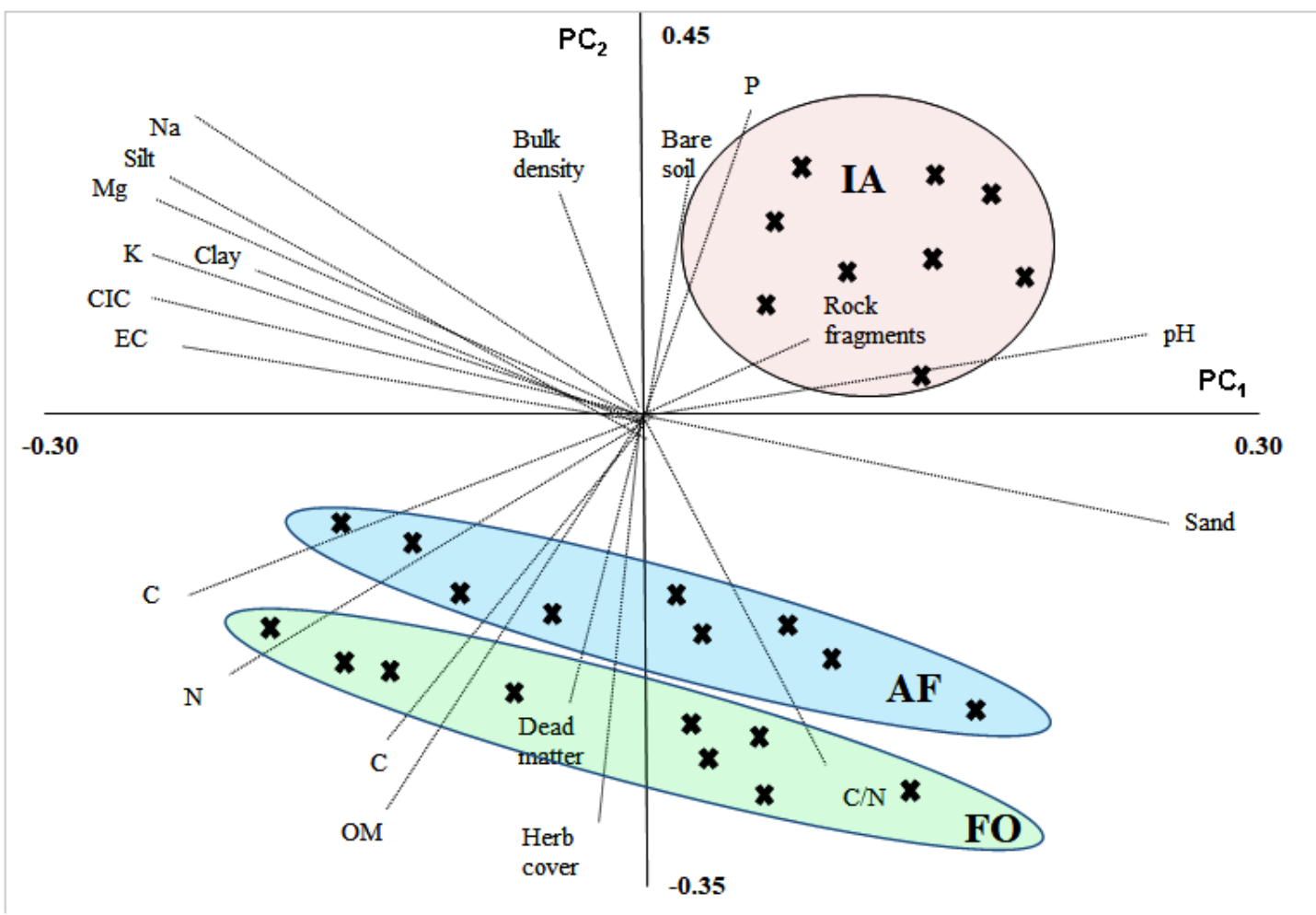

Figure 4. Principal component analysis applied to properties of soils subject to different land uses (AF: Abandoned Farmland; IA: Intensive Agriculture; FO: Forest) in the study area (Villamalea, Castilla La Mancha, SE Spain) (the ellipses represent the evident clusters achieved by coupling ANOVA and PCA and using land uses as factors). 
Table 4. Factor loadings on the first three principal components (PC) applied to properties of soils subjected to different land uses in the study area (Villamalea, Castilla La Mancha, SE Spain).

\begin{tabular}{|c|c|c|}
\hline \multirow{2}{*}{$\begin{array}{c}\text { Soil Properties } \\
\text { (Original Variables) }\end{array}$} & \multicolumn{2}{|c|}{ PCs } \\
\hline & $\mathrm{PC}_{1}(51 \%)$ & $\mathrm{PC}_{2}(37 \%)$ \\
\hline Rock & 0.111 & 0.113 \\
\hline Vegetation cover & -0.102 & -0.263 \\
\hline Bare soil & 0.088 & 0.347 \\
\hline Dead woodymatter & -0.070 & -0.268 \\
\hline Bulk density & 0.009 & 0.306 \\
\hline Sand content & 0.269 & -0.202 \\
\hline Silt content & -0.244 & 0.245 \\
\hline Clay content & -0.293 & 0.141 \\
\hline$p H$ & 0.311 & 0.054 \\
\hline Electrical conductivity & -0.312 & 0.051 \\
\hline Organic matter & -0.191 & -0.304 \\
\hline Total nitrogen content & -0.247 & -0.237 \\
\hline Phosphorous content & 0.097 & 0.365 \\
\hline Potassium content & -0.307 & 0.089 \\
\hline Sodium content & -0.230 & 0.264 \\
\hline Calcium content & -0.311 & -0.059 \\
\hline Magnesium content & -0.263 & 0.214 \\
\hline Total carbon content & -0.193 & -0.303 \\
\hline Cation Exchange Capacity & -0.310 & 0.070 \\
\hline
\end{tabular}

\section{Discussion}

Many studies have demonstrated how and by what extent land uses influence the physico-chemical and hydrological characteristics of soil (e.g., $[4,11,16,34,47])$. However, these characteristics also depend on the specific soil properties, such as texture and vegetal cover. For the investigated soils (sandy to clayey texture with variable vegetation cover), it has been shown that some of the chemical characteristics (namely $\mathrm{pH}, \mathrm{EC}, \mathrm{N}$ content and the $\mathrm{C} / \mathrm{N}$ ratio) were very similar among the investigated land uses. Conversely, significant gradients in the OM content and CEC, two very important soil properties regarding soil fertility and productivity, were noticed when comparing AF (showing the highest values) to soils subject to IA. This soil depletion in OM and CEC may be attributable to plant uptake, due to the crop growth [48]. Moreover, soil under IA has lower OM and higher $\mathrm{C} / \mathrm{N}$ ratio on average, although not optimal [49]; the other two land uses (AF and FO) have much less favorable $\mathrm{C} / \mathrm{N}$ ratio for plants.

The most important variations among the investigated land uses were noticed in the soil hydrological properties: SWR and SHC varied significantly among the experimental land uses. More specifically, the topsoil of forested land had a much higher SWR compared to the surface soils subject to IA and AF. Even a slight SWR of FO soil may have noticeable effects on water infiltration rates, generating more runoff-particularly in summer, when the soil is drier-and thus enhancing soil erosion [27]. However, although it has been reported that SWR is particularly common under rangeland or forestland such as permanent grassland and deciduous shrub and forest terrain [50-52], it can also occur on agricultural land [27]. SWR affects both coarse and fine-textured soils [21,29,53] and occurs at low to moderate water contents [26,54]. In particular, coarse-textured soils, as those of the forestland analyzed in this study, are more prone to water repellency, even when they are permanently vegetated [55]. The level of SWR depends on the soil particle fraction with a hydrophobic surface coating [52] and is influenced by the surface area of the particles, which varies considerably with soil texture [56]. Therefore, in the sandy soils of our forestland, which have the lowest surface area, a hydrophobic surface impacts a larger proportion of particles than for a loamy or clayey soil where the surface area is up to three orders of magnitude greater [56,57]. Moreover, the plant species surveyed in 
the forest of this study (eucalyptus and pines) are perennial trees with a considerable concentration of resins, waxes or aromatic oils, which have commonly been associated with SWR [58-60]. Under these conditions, it may be advisable to develop proper strategies to reduce SWR, such as a more effective soil management, the addition of clays to increase particle surface area, tillage to break-up and abrade hydrophobic surfaces and the use of chemical wetting agents [29,61]. Moreover, regions with a Mediterranean climate with prolonged dry periods, such as southern Spain, could be particularly affected by SWR and its hydrological impacts, which bring soils within a water content range in which SWR is exhibited $[18,62,63]$.

Conversely, SWR levels surveyed in the other two investigated land uses (IA and AF) are less severe. In the soils previously subjected to agricultural activities, plant natural succession after land abandonment helps to avoid or reduce SWR, contributing to water penetration into the deeper soil layers, thanks to preferential flow paths via plant roots and stem flow [64]. Regarding the plots subjected to IA, agricultural soils are usually considered wettable [29], even though some studies have found that soil management practices can induce water repellency also in cropped areas [30-32]. In general, tilled sites are virtually unaffected by SWR [55]; furthermore, cultivation promotes rainfall infiltration, and, as a consequence, the runoff and erosion rates are significantly reduced [65]. However, although runoff and erosion are mostly reduced after plowing, these processes may increase again over time because of crusting, especially in silty soils [66].

Beside the low SWR levels, the reduced SHC of forestland detected in this study, compared to soils subject to IA, deserves much attention. As a matter of fact, depending on the severity of SWR, such soils may have water infiltration rates lower than would be expected on the basis of their pore size distribution and SWC (e.g., [20,25]). The combination of a reduced wettability (due to high SWR) and low SHC may enhance surface runoff (e.g., [26,67]). With this type of land use, the exposure of soils to the highest and most erosive rainfalls in the experiment area during autumn/winter may aggravate the erosive risks. However, this particular hydrological response of forest sandy soils can be prevented by a proper ground cover and by natural vegetation, which, having a strong influence on soil hydrological properties, reduces soil erosion rates [68].

Also, in the AF of this study, a lower SHC was detected (of the same order of magnitude as FO), which may lead to the degradation of the ecosystem at least during the first $3-5$ years after abandonment [65]. This reduced SHC could be mainly due to the finer texture of AF soil compared to IA, but also the land use may have had a role. However, it has been demonstrated that, after land abandonment, the vegetation recovery should improve soil water-retention capacity and hydraulic conductivity, thus increasing infiltration and decreasing runoff and erosion rates [65,69]. In such a way, plant re-growth starts to control the hydrological and erosional soil response [64]. Moreover, the $\mathrm{C} / \mathrm{N}$ ratio of AF soils is less favorable than in agricultural soils (and this could be due to the absence of fertilizer applications), which subsequently influenced plant succession (depending on the duration of abandonment) [49].

Overall, the worse hydrological response of FO soils compared to IA and AF plots, detected in this study, suggest that, although the forest tree planting by reforestation has been adopted as a viable land management strategy in many parts of the Mediterranean basin, natural scrubland, similar as those of revegetation processes in AF, may be more appropriate with regard to water use efficiency and soil conservation measures, since they assure a lower SWR and a slightly higher SHC [18].

However, it must be understood that the SHC measurements of the tension infiltrometer carried out in this study relate to the unsaturated soil. This parameter may be initially more important than saturated hydraulic conductivity at the time scale of convective rainfall, which is typically short and only lasts 20-60 $\mathrm{min}$, common in many Mediterranean areas [70]. Since this investigation showed that soils of forestland and AF are affected by a lower SHC compared to agricultural areas, these land uses require caution in semi-arid or arid Mediterranean ecosystems, where runoff and soil erosion risks may be high. As a matter of fact, given that in the soils typical of this climatic context (in particular, those of prevalent sandy texture) the Hortonian (that is, infiltration-excess) overland flow type dominates over 
concentrated runoff, a reduction of SHC may worsen the hydrological behavior of soils subjected to these land uses, with a possible increase of water runoff and soil erosion [71]. In fact, a lower water infiltration rate increase reduces the water storage of soil during heavy storms, thus increasing the share of precipitation, which generates surface runoff $[16,47]$.

\section{Conclusions}

The effects of land use (abandoned farmland, intensive agriculture and natural forest) have been evaluated at the plot scale with particular reference to the physico-chemical properties, water content and repellency, and the hydraulic conductivity of soils. While most soil properties were not significantly different between the land uses, the hydraulic properties of the investigated soils showed specific responses to the different land uses or plant covers. Forest soils showed -high water repellency and low infiltrability, which worsens their hydrological behavior under heavy and frequent storms typical of the Mediterranean landscape. This behavior may increase the risks of soil erosion and pollutant runoff downstream in sloping areas. Abandoned soils previously subjected to agriculture showed a moderate water repellency, but their low hydraulic conductivity can cause serious problems in terms of runoff and soil erosion. However, shrub vegetation recovery, resulting from plant succession, can decrease this concern by increasing soil cover, which may reduce its erodibility. Compared to the forestland and the abandoned land, the agricultural soils were less affected by water repellency and low infiltrability, presumably due to the periodical tillage operations.

Overall, the main conclusion of this study is the important effect of land use on the hydrological characteristics of soils, and indirectly on their different susceptibility to surface runoff and erosion. This suggests paying attention to the specific land use and soil type under the Mediterranean climate (namely, steep sandy soils of forest ecosystems and also in the context of the expected climate changes), which may be affected by high runoff and erosion rates.

Author Contributions: Conceptualization, M.E.L.-B.; methodology, M.E.L.-B.; formal analysis, M.E.L.-B.; investigation, P.A.P.-Á., J.S., J.G.-R., and D.M.; resources, J.d.1.H.; data curation, D.A.Z. and M.E.L.-B.; writing—original draft preparation, D.A.Z.; writing—review and editing, D.A.Z. and M.E.L.-B.; supervision, V.Z. and J.B.; project administration, J.d.l.H.; funding acquisition, J.d.1.H.

Funding: This research received no external funding.

Acknowledgments: This study was supported by funds provided by the University of Castilla-La Mancha to the Forest Ecology Research Group. Also, by the Research Project from the Spanish National Institute for Agricultural and Food Research and Technology (INIA), VIS4FIRE (RTA2017-00042-C05). The authors thanks to Carlos Navarro, Beatriz Ariño and Jose Luis Martínez for the field assistance.

Conflicts of Interest: The authors declare no conflict of interest.

\section{References}

1. Cantón, Y.; Solé-Benet, A.; De Vente, J.; Boix-Fayos, C.; Calvo-Cases, A.; Asensio, C.; Puigdefábregas, J. A review of runoff generation and soil erosion across scales in semiarid south-eastern Spain. J. Arid Environ. 2011, 75, 1254-1261. [CrossRef]

2. Fortugno, D.; Boix-Fayos, C.; Bombino, G.; Denisi, P.; Quiñonero Rubio, J.M.; Tamburino, V.; Zema, D.A. Adjustments in channel morphology due to land-use changes and check dam installation in mountain torrents of Calabria (southern Italy). Earth Surface Process. Landf. 2017, 42, 2469-2483. [CrossRef]

3. García-Ruiz, J.M. The effects of land uses on soil erosion in Spain: A review. Catena 2010, 81, 1-11. [CrossRef]

4. Nunes, A.N.; De Almeida, A.C.; Coelho, C.O. Impacts of land use and cover type on runoff and soil erosion in a marginal area of Portugal. Appl. Geogr. 2011, 31, 687-699. [CrossRef]

5. Dunjó, G.; Pardini, G.; Gispert, M. The role of land use-land cover on runoff generation and sediment yield at a microplot scale, in a small Mediterranean catchment. J. Arid Environ. 2004, 57, 239-256. [CrossRef]

6. Grimm, M.; Jones, R.; Montanarella, L. Soil Erosion Risk in Europe; European Commission; Institute for Environment and Sustainability; European Soil Bureau: Hannover, Germany, 2011. 
7. Yassoglou, N.; Montanarella, L.; Govers, G.; Van Lynden, G.; Jones, R.J.A.; Zdruli, P. Soil Erosion in Europe. Technical Report for DG XI; European Soil Bureau: Hannover, Germany, 1998.

8. Cheng, Q. Soil erosion and ecological reestablishment in the Nianchu river valley in Tibet. Chin. J. Ecol. 2002, $21,74-77$.

9. Nunes, A.N.; Coelho, C.O.A.; De Almeida, A.C.; Figueiredo, A. Soil erosion and hydrological response to land abandonment in a central inland area of Portugal. Land Degrad. Dev. 2010, 21, 260-273. [CrossRef]

10. Trasar-Cepeda, C.; Leirós, M.C.; Gil-Sotres, F. Hydrolytic enzyme activities in agricultural and forest soils. Some implications for their use as indicators of soil quality. Soil Biol. Biochem. 2008, 40, 2146-2155. [CrossRef]

11. Lucas-Borja, M.E.; Calsamiglia, A.; Fortesa, J.; García-Comendador, J.; Guardiola, E.L.; García-Orenes, F.; Gago, J.; Estrany, J. The role of wildfire on soil quality in abandoned terraces of three Mediterranean micro-catchments. CATENA 2018, 170, 246-256. [CrossRef]

12. Solé-Benet, A. Spain. In Soil Erosion in Europe; Boardman, J., Poesen, J., Eds.; John Wiley \& Sons: Chichester, UK, 2006; pp. 311-346.

13. Lasanta, T.; Garcia-Ruiz, J.M.; Pérez-Rontomé, C.; Sancho-Marcén, C. Runoff and sediment yield in a semi-arid environment: The effect of the land management after farmland abandonment. CATENA 2000, 38, 265-278. [CrossRef]

14. MacDonald, D.; Crabtree, J.R.; Wiesinger, G.; Dax, T.; Stamou, N.; Fleury, P.; Lazpita, J.G.; Gibon, A. Agricultural abandonment in mountain areas of Europe: Environmental consequences and policy response. J. Environ. Manag. 2000, 59, 47-69. [CrossRef]

15. Burke, S.M.; Thornes, J.B. A thematic review of EU Mediterranean desertification research in Frameworks III and IV: Preface. Adv. Environ. Monit. Model 2004, 1, 1-14.

16. Lucas-Borja, M.E.; Zema, D.A.; Carrà, B.G.; Cerdà, A.; Plaza-Alvarez, P.A.; Cózar, J.S.; Gonzalez-Romero, J.; Moya, D.; de las Heras, J. Short-term changes in infiltration between straw mulched and non-mulched soils after wildfire in Mediterranean forest ecosystems. Ecol. Eng. 2018, 122, 27-31. [CrossRef]

17. Trabaud, L. Man and fire: Impacts on Mediterranean vegetation. In Mediterranean-Type Shrublands; di Castri, F., Goodall, D.W., Specht, R.L., Eds.; Elsevier: Amsterdam, The Netherlands, 1996; pp. 523-537.

18. Cerdà, A.; Doerr, S.H. Soil wettability, runoff and erodibility of major dry-Mediterranean land use types on calcareous soils. Hydrol. Process. 2007, 21, 2325-2336. [CrossRef]

19. Markus, F.; Hannes, F.; William, A.J.; Leuenberger, J. Susceptibility of soils to preferential flow of water: A field study. Water Resour. Res. 1994, 30, 1945-1954.

20. Doerr, S.H.; Shakesby, R.A.; Walsh, R.P.D. Soil hydrophobicity in north-west Europe: Its occurrence and implications for modelling soil hydrological response. In Second Inter-Celtic Colloquium on Hydrology and the Management of Water Resources, 3-7 July; British Hydrological Society Occasional Paper; British Hydrological Society: London, UK, 2000; Volume 11, pp. 211-218.

21. Doerr, S.H.; Shakesby, R.A.; Walsh, R.P.D. Soil water repellency: Its causes, characteristics and hydro-geomorphological significance. Earth-Sci. Rev. 2000, 51, 33-65. [CrossRef]

22. Taumer, K.; Stoffregen, H.; Wessolek, G. Seasonal dynamics of preferential flow in a water repellent soil. Vadose Zone, J. 2006, 5, 405-411. [CrossRef]

23. McKissock, I.; Gilkes, R.J.; Harper, R.J.; Carter, D.J. Relationships of water repellency to soil properties for different spatial scales of study. Aust. J. Soil Res. 1998, 36, 495-507. [CrossRef]

24. Brevik, E.C.; Cerdà, A.; Mataix-Solera, J.; Pereg, L.; Quinton, J.N.; Six, J.; Van Oost, K. The interdisciplinary nature of SOIL. Soil 2015, 1, 117-129. [CrossRef]

25. DeBano, L.F. The effect of hydrophobic substances on water movement in soil during infiltration. Proc. Soil Sci. Soc. Am. 1971, 35, 340-343. [CrossRef]

26. Doerr, S.H.; Ferreira, A.J.D.; Walsh, R.P.D.; Shakesby, R.A.; Leighton-Boyce, G.; Coelho, C.O.A. Soil water repellency as a potential parameter in rainfall-runoff modelling: Experimental evidence at point to catchment scales from Portugal. Hydrol. Process. 2003, 17, 363-377. [CrossRef]

27. Cerdà, A.; Doerr, S.H. Influence of vegetation recovery on soil hydrology and erodibility following fire: An 11-year investigation. Int. J. Wildland Fire 2005, 14, 423-437. [CrossRef]

28. Eynard, A.; Schumacher, T.E.; Lindstrom, M.J.; Malo, D.D. Effects of agricultural management systems on soil organic carbon in aggregates of Ustolls and Usterts. Soil Tillage Res. 2005, 81, 253-263. [CrossRef]

29. Wallis, M.G.; Horne, D.J. Soil water repellency. In Advances in Soil Science; Stewart, B.A., Ed.; Springer: New York, NY, USA, 1992; Volume 20, pp. 91-146. 
30. Blanco-Canqui, H. Does no-till farming induce water repellency to soils? Soil Use Manag. 2011, $27,2-9$. [CrossRef]

31. Blanco-Canqui, H.; Lal, R. Extent of soil water repellency under long-term notill soils. Geoderma 2009, 149, 171-180. [CrossRef]

32. García-Moreno, J.; Gordillo-Rivero, Á.J.; Zavala, L.M.; Jordán, A.; Pereira, P. Mulch application in fruit orchards increases the persistence of soil water repellency during a 15-years period. Soil Tillage Res. 2013, 130, 62-68. [CrossRef]

33. Romero Diaz, A.; Barbera, G.G.; Lopez Bermudez, F. Relationship between soil erosion, rainfall and vegetation cover in the semiarid environment of south east of Iberian Peninsula. In Proceedings of the Conference on Erosion and Land Degradation in the Mediterranean, Aveiro, Portugal, 14-18 June 1995; pp. 59-73.

34. Vacca, A.; Loddo, S.; Ollesch, G.; Puddu, R.; Serra, G.; Tomasi, D.; Aru, A. Measurement of runoff and soil erosion in three areas under different land use in Sardinia (Italy). CATENA 2000, 40, 69-92. [CrossRef]

35. Kottek, M.; Grieser, J.; Beck, C.; Rudolf, B.; Rubel, F. World Map of the Köppen-Geiger climate classification updated. Meteorologische Zeitschrift 2006, 15, 259-263. [CrossRef]

36. FAO-UNESCO. Soil Map of the World, 1:5,000,000; UNESCO: Paris, France, 1981.

37. IUSS Working Group WRB. World Reference Base for Soil Resources 2014. International Soil Classification System for Naming Soils and Creating Legends for Soil Maps. Update 2015; World Soil Resources Report 106; FAO: Rome, Italy, 2015; p. 188.

38. Guitián, F.; Carballas, T. Técnicas de análisis de suelos; Ed. Pico Sacro: Santiago de Compostela, Spain, 1976.

39. Nelson, D.W.; Sommers, L.E. Total carbon, organic carbon, and organic matter. In Methods of Soil Analysis, Part 3; Sparks, D.L., Page, A.L., Helmke, P.A., Loeppert, R.H., Eds.; SSSA Book Series; American Society of Agronomy: Madison, WI, USA, 1996; pp. 961-1010.

40. Hedo, J.; Lucas-Borja, M.E.; Wic, B.; Andrés Abellán, M.; De las Heras, J. Experimental site and season over-control the effect of Pinus halepensis in microbial properties of soil under semiarid and dry conditions. J. Arid Environ. 2015, 116, 44-52. [CrossRef]

41. Bremmer, J.M.; Mulvaney, C.S. Nitrogen-Total. In Methods of Soil Analysis; Page, A.L., Miller, R.H., Keeney, D.R., Eds.; American Society of Agronomy: Madison, WI, USA, 1982; pp. 595-624.

42. Olsen, S.R.; Cole, C.V.; Watanabe, F.S.; Dean, L.A. Estimation of Available Phosphorus in Soils by Extraction with Sodium Bicarbonate; Circular 939; U.S. Department of Agriculture: Washington, DC, USA, 1954; pp. 1-19.

43. Thomas, G.W. Exchangeable Cations. In Methods of Soil Analysis; Page, A.L., Miller, R.H., Keeney, D.R., Eds.; American Society of Agronomy: Madison, WI, USA, 1982; pp. 159-165.

44. Decagon Devices. Minidisk Infiltrometer User's Manual Version 10; Decagon Devices: Pullman, WA, USA, 2012.

45. Zhang, R. Determination of soil sorptivity and hydraulic conductivity from the disk infiltrometer. Soil Sci. Soc. Am. J. 1997, 61, 1024-1030. [CrossRef]

46. Doerr, S.H. On standardizing the 'water drop penetration time' andthe 'molarity of an ethanol droplet' techniques to classify soil hydrophobicity: A case study using medium textured soils. Earth Surf. Process. Landf. 1998, 23, 663-668. [CrossRef]

47. Plaza-Álvarez, P.A.; Lucas-Borja, M.E.; Sagra, J.; Zema, D.A.; González-Romero, J.; Moya, D.; De las Heras, J. Changes in soil hydraulic conductivity after prescribed fires in Mediterranean pine forests. J. Environ. Manag. 2019, 232, 1021-1027. [CrossRef]

48. Zema, D.A.; Bombino, G.; Andiloro, S.; Zimbone, S.M. Irrigation of energy crops with urban wastewater: Effects on biomass yields, soils and heating values. Agric. Water Manag. 2012, 115, 55-65. [CrossRef]

49. Brady, N.C.; Weil, R.R. The Nature and Properties of Soils, 13th ed.; Prentice Hall: Upper Saddle River, NJ, USA, 2002.

50. Cerdà, A. Changes in overland flow and infiltration after a rangeland fire in a Mediterranean scrubland. Hydrol. Process. 1998, 12, 1031-1042. [CrossRef]

51. Cerdà, A. Postfire dynamics of erosional processes under Mediterranean climatic conditions. Zeitschrift fur Geomorphologie 1998, 42, 373-398.

52. Doerr, S.H.; Shakesby, R.A.; Dekker, L.W.; Ritsema, C.J. Occurrence, prediction and hydrological effects of water repellency amongst major soil and land-use types in a humid temperate climate. Eur. J. Soil Sci. 2006, 57, 741-754. [CrossRef]

53. DeBano, L.F. Water repellency in soils: A historical overview. J. Hydrol. 2000, 231-232, 4-32. [CrossRef] 
54. Dekker, L.W.; Ritsema, C.J. Variation in water content and wetting patterns in Dutch water repellent peaty clay and clayey peat soils. CATENA 1996, 28, 89-105. [CrossRef]

55. Doerr, S.H.; Ritsema, C.J.; Dekker, L.W.; Scott, D.F.; Carter, D. Water repellence of soils: New insights and emerging research needs. Hydrol. Process. Int. J. 2007, 21, 2223-2228. [CrossRef]

56. Hallett, P.D.; Gaskin, R.E. An introduction to soil water repellency. In Proceedings of the 8th International Symposium on Adjuvants for Agrochemicals (ISAA2007), Columbus, OH, USA, 6-9 August 2007; International Society for Agrochemical Adjuvants: Wageningen, The Netherlands, 2007.

57. Woche, S.K.; Goebel, M.O.; Kirkham, M.B.; Horton, R.; Van der Ploeg, R.R.; Bachmann, J. Contact angle of soils as affected by depth texture and land management. Eur. J. Soil Sci. 2005, 56, 239-251. [CrossRef]

58. Mataix-Solera, J.; Doerr, S.H. Hydrophobicity and aggregate stability in calcareous topsoils from fire-affected pine forests in southeastern Spain. Geoderma 2004, 118, 77-88. [CrossRef]

59. Granged, A.J.P.; Zavala, L.M.; Jordàn, A.; Munoz-Rojas, M.; Mataix-Solera, J. Short-term effects of experimental fire for a soil under eucalyptus forest (SE Australia). Geoderma 2011, 167-168, 125-134. [CrossRef]

60. González-Peñaloza, F.A.; Cerdà, A.; Zavala, L.M.; Jordán, A.; Giménez-Morera, A.; Arcenegui, V. Do conservative agriculture practices increase soil water repellency? A case study in citrus-cropped soils. Soil Tillage Res. 2012, 124, 233-239. [CrossRef]

61. Hallett, P.D. A brief overview of the causes, impacts and amelioration of soil water repellency-A review. Soil Water Res. 2008, 3, 521-528. [CrossRef]

62. Dekker, L.W.; Doerr, S.H.; Oostindie, K.; Ziogas, A.K.; Ritsema, C.J. Water repellency and critical soil water conent in a dune sand. Soil Sci. Soc. Am. J. 2001, 65, 1667-1674. [CrossRef]

63. Verheijen, F.G.A.; Cammeraat, L.H. The association between three dominant shrub species and water repellent soils along a range of soil moisture contents in semi-arid Spain. Hydrol. Process. 2007, 21, 2310-2316. [CrossRef]

64. Cammeraat, E.L.; Cerdà, A.; Imeson, A.C. Ecohydrological adaptation of soils following land abandonment in a semi-arid environment. Ecohydrology 2010, 3, 421-430. [CrossRef]

65. Cerdà, A. The effect of patchy distribution of Stipa tenacissima L. on runoff and erosion. J. Arid Environ. 1997, 36, 37-51. [CrossRef]

66. Keesstra, S.; Pereira, P.; Novara, A.; Brevik, E.C.; Azorin-Molina, C.; Parras-Alcántara, L.; Jordán, A.; Cerdà, A . Effects of soil management techniques on soil water erosion in apricot orchards. Sci. Total Environ. 2016, 551, 357-366. [CrossRef] [PubMed]

67. Megahan, W.F.; Molitor, D.C. Erosional effects of wildfire and logging in Idaho. In Proceedings of the Symposium on Watershed Management, American Society of Civil Engineers, Cogan, UT, USA, 14-16 August 1975; pp. 423-444.

68. Prosser, I.P.; Williams, L. The effect of wildfire on runoff and erosion in native Eucalyptus forest. Hydrol. Process. 1998, 12, 251-265. [CrossRef]

69. Lesschen, J.P.; Cammeraat, L.H.; Kooijman, A.M.; van Wesemael, B. Development of spatial heterogeneity in vegetation and soil properties after land abandonment in a semi-arid ecosystem. J. Arid Environ. 2008, 72, 2082-2092. [CrossRef]

70. Moody, J.A.; Shakesby, R.A.; Robichaud, P.R.; Cannon, S.H.; Martin, D.A. Current research issues related to post-wildfire runoff and erosion processes. Earth Sci. Rev. 2013, 122, 10-37. [CrossRef]

71. Shakesby, R.A. Post-wildfire soil erosion in the Mediterranean: Review and future research directions. Earth Sci. Rev. 2011, 105, 71-100. [CrossRef]

(C) 2019 by the authors. Licensee MDPI, Basel, Switzerland. This article is an open access article distributed under the terms and conditions of the Creative Commons Attribution (CC BY) license (http://creativecommons.org/licenses/by/4.0/). 